\title{
'Dominance by birthright'? Reconfiguration of firm boundaries to acquire new resources and capabilities
}

\section{Introduction}

Innovative 'green' technologies might remain as niches facing otherwise insurmountable sociotechnical regimes. Entrepreneurial 'green' entrants need to compete with the incumbents in order to survive and grow. The literature on industry lifecycles provides a good understanding of new entrant behaviour, survival and shakeout. Each entrant brings along and leverages a distinct set of pre-entry resources and capabilities (R\&Cs) into its new operations in the target industry (Teece and Pisano, 1994). Some researchers (Klepper and Simons, 2000; Kim and Park, 2006) argued that the survival of the entrant is their birthright i.e. the survival of new entrant is determined by their pre-entry R\&Cs. The persistence of early entrants, however, remains an understudied field (Gomez et al., 2016). Historical study of brewing industry in the U.S. (Walter et al., 2014) also suggested that de alio firms with stronger pre-entry R\&Cs particularly dynamics capabilities survived the increasing competitive pressure.

The focus on pre-entry R\&Cs in firm survival raises two key questions: (i) which pre-entry R\&Cs matter most in firm survival in the new industry? and (ii) What are the possible strategies to stay competitive in regard to their pre-entry R\&Cs? In order to answer the first question, we need to examine the taxonomy of R\&Cs. The ownership of R\&Cs determines firm competitiveness and thereby firm survival (Penrose, 1959). Arguably, this view of firm survival is equally applicable to any new entrant who is exploiting its R\&Cs in the new industry (Klepper, 2002a). Helfat and Lieberman (2002) distinguish between two categories of entrants' R\&Cs - 'core' and 'complementary' - which are context-free. We argue that further classification is required for a more useful taxonomy of entrant R\&Cs. There is a potentially long list of core R\&Cs ranging from the technology required for production to skills in marketing of the products. The decision to enter into a new industry obviously cannot be based 
on complete accumulation of every one of the core R\&Cs. Managers need to be able to assess the opportunity of entry and subsequent strategy for survival or growth based on incomplete information. Our study, based on the case of biofuel sector, proposes that core R\&Cs need to the further classified based on whether the $\mathrm{R} \& \mathrm{C}$ are criticality and ease of acquisition, which are context dependent and would be more meaningful for managers making entry decisions.

As for the second question about competitive strategies for pre-entry R\&Cs, studies of firm evolution (e.g., Nelson and Winter, 1982; Jacobides et al., 2009; Helfat, 2015) suggest that a firm's prior experience could lubricate or impose constraints on the evolution of the configuration and governance of the value chain. The embedded historical context of a firm, described as fundamental forces - alongside other market and institutional forces - shapes industrial structure (Geels, 2010). Shifting firm boundaries and the rationale for expanding into other stages of the value chain, thereby changing the vertical structure, are path dependent (Kim and Park, 2006). In a study of the U.S. biofuel value chain, Qian et al. (2012) found that a firm has a higher likelihood of internalizing a stage in the value chain where it has pre-entry experience. This is equally applicable to de alio firms with integrative capability and de novo firms with related founder's experience. Nonetheless, the question remains as to whether a firm should extend to a stage in the value chain where it does not have any pre-entry experience.

In weighting their chance of survival and growth in the biofuel sector, entrants actively acquire critical R\&Cs, thereby expanding the firm's boundary along the vertical supply chain by internalizing other activities irrespective of their pre-entry R\&Cs. We find evidence of path dependency, but also evidence of the possibility of breaking away from path dependency. Our study provides support on the changes of firm boundary particularly in seeking new R\&Cs, which are critical for their survival and growth in this new industry. We find evidence in the evolution of the biofuel sector of a trend towards bi-directional vertical integration. 
Downstream firms integrate backward and upstream firms integrate forward in order to actively pursue R\&Cs, contradicting both the path-dependent view and the view that firms will seek to expand to occupy the more profitable, higher value, segment(s) of any value chain.

In Section 2, we present a literature review on past studies of the R\&Cs of new entrants. We then offer a brief description of the development of the biofuel sector through 2012 in Section 3. Section 4 expands on the methodology and data used in our research. In Section 5, we analyze the major entrants and reclassify their pre-entry R\&Cs. We then attempt to explain the phenomenon of bi-directional vertical integration in Section 6, where firms extend their control up and down along the value chain. In Section 7, we propose an extension to the $\mathrm{R} \& \mathrm{C}$ taxonomy for entrants and conclude by describing how firms, building on the advantages found in their pre-entry R\&Cs, seek to control critical R\&Cs, which they were deprived of at birth.

\section{Entrants and pre-entry experience}

Entrants and their pre-entry experience exert a key influence on industry evolution. A standard theme in the strategy literature is to compare the competitive advantage of an established firm with that of a young and dynamic firm entering a new industry (Ganco and Agarwal, 2009). On one hand, established (or de alio) firms diversifying from another industry (Carroll et al., 1996) will possess relevant resources and distinctive competencies gained in their previous industry, which can be leveraged into the new operations (Teece and Pisano, 1994; Klepper and Simons, 2000, Uzunca, 2018), rendering de novo entrants to have few or no opportunities to survive (Knudsen et al., 2014). There are various theories on different types of 'everagable' R\&Cs - or core competencies, which are defined as the 'bundle of skills and technologies' (Hamel and Prahalad, 1994: 199) that enables services to be delivered to customers. On the other hand, new (or de novo) start-up entrants (Carroll et al., 1996) do not carry the baggage of older firms (Barnett and Carroll, 1995) nor do they display the same inertia (Haveman, 1992) and are, 
therefore, more flexible and adaptable in meeting the fresh challenges confronting a new industry. Debate persists over the types and characteristics of industries - e.g. the role of technology innovation, market size and power, or industrial policy (Mingo and Khanna, 2013) - that can impact on the success of either type of entrant.

Despite the acknowledged importance of entrant background, there are surprisingly few studies by industrial economists and strategy scholars on 'where entrants come from and how their backgrounds affect their fates' (Klepper and Simons, 2000: 998). The studies that have analyzed the background of firms suggest that their histories do have an effect on their survival (Carroll et al., 1996; Klepper, 2002b; Helfat and Lieberman, 2002; Thompson, 2005). Klepper and Simons (2000) propose that de alio firms with prior experience in the value chain are more likely to survive. Empirical studies have been conducted with respect to manufacturing firms in general (Bellone et al., 2008) as well as specific industries such as automobiles (Klepper, 2002a); television transmission (Klepper and Simons, 2000); high-technology (Klepper and Sleeper, 2005); shipbuilding (Thompson, 2005); lasers (Buenstorf, 2007), green industries (de Silva et al., 2017), and agricultural biotechnology sector (Moeen, 2017).

Moreover, the survival and competitiveness of a firm also depends on the type of R\&Cs at the firm's disposal (Penrose, 1959; Wernerfelt, 1984), which highlights the need for a new entrant to capitalize on the R\&Cs it brings to the new industry. Vidal and Mitchell (2013) propose that entrants need to develop complementary resources, and Finney et al. (2008) point to reinventing the firms' resource base but provide few additional details. Moeen (2017) further demonstrates that a firm's integrative capability, at the stage of initial investment prior to the point of entry into a nascent industry, is an important factor in entry decisions, particularly for technologyrelated sectors.

We adopt the definitions proposed by Helfat and Peteraf (2003: 999): 'A resource refers to an 
asset or input to production (tangible or intangible) that an organization owns, controls, or has access to on a semi-permanent basis. An organizational capability refers to the ability of an organization to perform a coordinated set of tasks, utilizing organizational resources, for the purpose of achieving a particular end result.' Helfat and Lieberman (2002) provide a useful classification of entrants' R\&Cs into 'core' and 'complementary' in making a decision on market entry. 'Core' R\&Cs refer to knowledge required to create a product or service such as technological knowledge or customer needs; whereas 'Complementary' R\&Cs are needed to support the 'Core' in order to generate profits such as through finance and customer services. However, these context-free classifications have their limitations, particularly in terms of understanding core capabilities - core R\&Cs for one industry might not be 'core' for another. Therefore, we propose a further subdivision of core R\&Cs into critical or not critical R\&Cs, which depends on examining the specifics of different industries. Critical R\&Cs might be easily accumulated or acquired within a reasonably short period of time, therefore, the next level of the taxonomy is ease of acquisition. The authors propose the following taxonomic structure of pre-entry R\&Cs:

[Insert Figure 1 here]

Contextual factors can play an influential role in the industry evolution of vertical firm structure (Gibbon and Ponte, 2005: 82; Helfat, 2015). The evolution of vertical structure depends on many factors. The early understanding of this evolution adopts an efficiency perspective. Stigler (1951), building on Adam Smith's division of labor, suggested that new industry evolves from a vertically integrated firm towards vertical dis-integration to reduce production costs as the market size expands and technology becomes more mature in order to support economies of scale at different stages of production. It will then begin to re-integrate after the market size declines. Coase (1973) and later Williamson (1985) extended this argument to include 
transaction costs in addition to production costs in the analysis of the structure of economic organizations. As transaction cost theory was becoming increasingly prominent, Eisenhardt (1989) argued that the principal-agent dilemma warranted taking into account internal managerial costs in vertical integration decisions. Specific factors related to products and technology are equally important, for example, the degree of product standardization and codifiability (Jacobides, 2005), a firm's innovative capabilities and resources (Wernerfelt, 1984), and low cost or differentiated innovative products (Helfat and Campo-Rembado, 2016). The other main alternative explanation of vertical structure evolution is an institutional perspective (Williamson, 1996), which involves market power (Stuckey, 1983), barriers to entry (Riordan, 2008), and relational factors (Gereffi et al., 2005)

\section{Rapid expansion of the biofuel sector through 2012}

The global biofuel industry expanded rapidly over two decades peaking in 2010. After 2012, global production has roughly stabilized (RFA, 2016), as has policy innovation. We focus our study on the bio-ethanol segment of the industry, rather than biodiesel, since bioethanol production volumes have been much larger and hence the sector is more mature. The production of bioethanol grew from 30.7 billion liters in 2000 to an estimated 104.5 billion liters in 2012 , equivalent to an average annual growth rate of $10.7 \%$ (F.O. Licht, 2012). The size of the biofuel industry (where fuel-ethanol is the major type of biofuels) in 2017 was about $3 \%$ of the global transport energy consumption (2.8 billion tonnes of oil equivalent) (BP, 2018), which is not insignificant. Since 2012, global growth has slowed to about 5\% per annum (Based on F.O. Licht's World Ethanol and Biofuels Reports).

Bioethanol has been produced around the globe - Brazil has historically been the largest producer in the world but was overtaken by the U.S. in 2006. By the end of 2012, the U.S. and Brazil were producing about 53 billion liters (51\% of world production) and 23 billion liters 
(22\%) respectively.

In terms of the market, roughly $80 \%$ of global bioethanol production the first decade of $21^{\text {st }}$ century was supplied to the transportation fuel-ethanol market, as an additive/substitute for gasoline in the transportation fuel market. This market was the main driver of growth in production. The remaining $20 \%$ of production serves the rather stable industrial and beverage sectors (F.O. Licht, 2012).

The development of the fuel-ethanol market is primarily driven by market forces - for instance, high oil prices and relatively lower ethanol prices over the period in question - and government policies with varying objectives such as mitigating climate change, energy security, supply chain management, consumer adoption, rural development, job creation and development of biotechnologies (Wiesenthal, et al., 2009; Chen and Wang, 2017; Ye et al., 2018). By 2010, more than fifty countries had adopted policies either to create domestic markets or to develop production capabilities for biofuels (IEA, 2011), despite the unsettled debate on the sustainability of biofuel industry.

Consequently, biofuels rapidly gained market share, especially in Brazil, the U.S., Europe and China. Fuel-ethanol, for example, accounted for about $6 \%$ of the global gasoline market in 2010, having increased its market share four-fold over the decade from $1.4 \%$ in 2000 (EIA, 2013). Brazil saw the deepest penetration of fuel-ethanol, rising from $22.4 \%$ in 2000 to roughly $50 \%$ of motor vehicle fuel consumption after 2008 . The growth of ethanol penetration was even more rapid in the U.S. - the largest gasoline-consuming country with more than $40 \%$ of the world consumption - rising from $1.2 \%$ in 2000 to $8.5 \%$ in 2010 .

The bioethanol value chain was formed by combining the upstream part of the agro-food chain with the downstream part of the transportation fuel chain. The new value chain can be divided into three distinct production stages - upstream agro-food commodity, midstream 
manufacturing, and downstream transportation fuel. As shown in Figure 2, the industry diverts raw materials from food-feed agricultural chains to produce a product substituting and competing with the downstream petroleum value chain (indicated by the thinner shaded gray arrows).

[Insert Figure 2 here]

\section{Methodology and data}

This is a case study on entrants in biofuel industry using multiple sets of data. The primary data is based on semi-structured interviews with producers and expert interviews conducted from 2009 to 2012. The key ethanol producers interviewed include large firms e.g. Abengoa, BP, Petro China, and COFCO China, and smaller firms, e.g. Thai Oil, Saigon Petro, Zhongke Tianyuan New Energy (Guangzhou China), Bronzeoak (UK and the Philippines), Petro Vietnam (Petrosetco). We have also interviewed technology providers, e.g. Alfa-Laval, Bosch. The informants were senior leaders and managers including chairs, directors, and top managers of leading producers. The length of the interview varied from relatively short discussions to those lasting for about an hour. In addition, we interviewed other stakeholders, i.e. policy makers and researchers, employees of oil companies, representatives of trade associations, farmers and traders. All interviews were conducted face-to-face. Follow-up questions were done via email, Skype, and telephone. The main language was English with the exception of interviews in China, which were conducted in the Chinese language by one of the co-authors. Interview notes were taken in all instances; some interviewees objected to any audio recording. This textured data is used in thematic analysis to identify the R\&Cs in accordance with the proposed taxonomical structure of pre-entry R\&Cs (as in Figure 1) and the data is presented in greater detail in Table 2 and Table 3 in Section 5.

The secondary data (both quantitative and qualitative) also come from diverse sources, e.g. 
industrial reports, company websites, and media coverage. The main data sources are the U.S. Renewable Fuels Association (RFA), the Brazilian Sugarcane Industry Association (UNICA) and industry reports (e.g. F.O. Licht). Given the global scope and fluidity of this sector, there are some inconsistencies in data. It is challenging, for example, to obtain accurate data for company production information for a new industry with many firms based in developing countries. Nevertheless, these uncertainties do not impede the main analysis and any other major discrepancies could be reconciled by triangulating using diverse sources as suggested by Huberman and Miles (1994).

\subsection{Identification and Ranking of Global Ethanol Manufacturers}

We identified and ranked the top-thirty ethanol manufacturers (see Appendix A) based on a review of production levels and installed capacity of the top manufacturers in major producing regions and estimating their market share up to the end of 2012. This is because at this point the rapid growth of the 2000s was beginning to slow and the industry had reached a more mature phase where the turmoil in the ranking of most of the leading manufacturers had begun to settle. We acknowledge that this approach inevitably produces a selection bias towards more successful firms. Nonetheless, the specifics of firm shakeouts and survival evolution are not the aim of our study. We seek to understand how successful large firms evolve after entering the biofuel sector, with a focus on entrants and vertical movement. In order to do so, we also track the historical evolution to examine when a firm first enters a specific stage of the new value chain. We did not take into account the role of many small/start-up firms - particularly those involved in the development of advanced biofuels. Despite they might have significant influence on the industrial structure in the future, they have a limited influence over the period of this study. 


\subsection{Classification of entrants and their pre-entry resources and capacities}

Based on Appendix A, a classification was carried out with respect to the firms' pre-entry industry and the key R\&Cs they brought to the new industry. The pre-entry backgrounds of the manufacturers were very diverse and could be classified into two main categories i.e. de alio and de novo. De alio entrants were those entrants with prior involvement in at least some stages of the biofuel value chain. They could be further divided in accordance with the form of prior involvement at the stages of what would become the new biofuels supply chain, as research has indicated systematic differences in performance of entrants with different backgrounds (Helfat and Leiberman, 2002). Based on our sample of the largest manufacturers, de alio entrants not only came from agricultural and fossil fuel sectors but also were technology and engineering firms. We therefore proposed four groups of entrants in accordance with their historical core business as shown in Table 1: (i) technology, (ii) farming \& food processing, (iii) agro-food commodity trading, and (iv) oil \& gas ${ }^{1}$.

\section{[Insert Table 1 here]}

We define de novo entrants without differentiating between start-ups and entrepreneurial spinoffs, which are, by definition, lacking in some of the R\&Cs owned by the diversified de alio entrants (Chen et al., 2012). We acknowledge that entrepreneurial spin-offs, where the founder has prior experience in a related industry or has been employed by an incumbent, could possess certain relevant R\&Cs (Shepherd and de Tienne, 2004; Roberts et al., 2011). Despite the

\footnotetext{
${ }^{1}$ We do not categorize entrants based on their very first business activity but rather on their core business before entry into biofuel manufacturing. There are, of course, some difficulties in categorizing some firms. For example, POET, which began with a farming industry background prior to 1986, moved into developing technology for its ethanol facility. Gradually, the firm grew substantially as a provider of technology and plant building services during the 1990s (POET, 2013), which we use as its core business prior to its major entry into biofuel manufacturing.
} 
possible contribution of a founder's prior experience, there are three reasons for taking this approach to classification. First, we propose that a firm's combinative R\&Cs (Kagut and Zander, 1992) is significantly more important than the R\&Cs controlled by any individual, given the nature and the scale of operations in biofuel industry. While firms can transfer some combinative R\&Cs to the new industry such as via sourcing and securing feedstock or access to marketing channels, this is not possible for an individual founder (Helfat and CampoRembado, 2016). Second, the differences in individual-level R\&Cs are less significant given the size of the firms in our sample, i.e., the thirty largest global manufacturers. Third, even though individual $\mathrm{R} \& \mathrm{C}$ could be useful, any new entrant could probably acquire those $\mathrm{R} \& \mathrm{Cs}$ without substantial difficulty, as discussed below.

The first group of de alio entrants is engineering and technology firms (Group 1). They were among the largest ethanol firms in terms of installed capacity during the study period (Table 1). These firms began by providing services in the design and building of ethanol facilities. They entered the ethanol-manufacturing stage to capitalize on their technical knowhow in the operation and management of such facilities. They also have the capabilities to perform R\&D on advanced biofuel technologies, potentially gaining key longer-term competitive advantages against other manufacturers primarily depend on ethanol production using traditional (first generation) biofuel technologies.

Group 2 is made up of firms that have been active in the agricultural and food sector, often for many decades. This is a prominent group with a large number of firms (Table 1), who were among the earliest entrants, and is the largest group in terms of production capacity. They are farmers, farm cooperatives (particularly in the U.S.), and agro-food and sweetener producers that enjoy a high level of security of feedstock supply due to their extensive pre-entry R\&Cs in agriculture-related sectors. These R\&Cs in feedstock production and sourcing were built up 
over their long history of involvement in cultivation, management, trade and processing of the feedstock used in biofuel production. Their competitive advantage would be difficult to acquire. Other firms would require a long time to build up these R\&Cs, particularly in a market where feedstock liquidity is low. For instance, there are more of these firms in countries (such as Brazil) where feedstock liquidity is low due to asset specificity, compared with countries with higher liquidity in the feedstock market (e.g. U.S.) ${ }^{2}$. Capitalizing on these R\&Cs, many firms in Group 2 were able to successfully integrate downstream into ethanol manufacturing and expand their installed capacity substantially within a short period.

Similarly, the agricultural commodity traders in Group 3 entered into the production stage by leveraging their pre-entry knowledge of feedstock supply and markets. These firms have a strong ability to couple their access to capital with a good understanding of global supply chains, trade and markets for feedstock and ethanol. These served as their key competitive advantages when they moved from providing services as traders into ethanol production.

Group 4 consists of firms active in the traditional petroleum value chain. Historically, they have been the downstream customers of ethanol manufacturers but some have decided to enter the upstream ethanol value chain directly. We have documented both vertically integrated oil companies and independent refiners investing heavily in ethanol-manufacturing assets. They brought along R\&Cs that were nearly impossible for firms in any other groups to match, such as knowledge of blending and the use of additives in the final products, logistics and infrastructure, and distribution and retail networks.

Group 5 is made up of start-ups with generally little previous background in biofuel-related sectors. They usually entered the market to capitalize on favorable government policies towards

\footnotetext{
2 The main feedstock for biofuel production in Brazil is sugarcane, which is costly to transport for a long distance and the quality deteriorates quickly over time. The U.S. biofuel feedback is mainly corn which is less bulky than sugarcane.
} 
ethanol manufacturing and its use as a transportation fuel. Some of these de novo firms expanded quickly, for example, Verasun rose to top the list of global manufacturers for a short time in 2008-9. In general, though, the leading manufacturers in Group 5 were typically smaller in size than firms in other groups (Appendix A).

Despite their dynamism, these de novo firms are vulnerable to the lack of R\&Cs in comparison with de alio firms found in the other groups. For instance, during the 2008 global financial crisis many Group 5 firms (including Verasun, Pacific Ethanol, Aventine Renewable Energy, Panda Ethanol and Renew Energy) faced liquidity problems. The U.S. oil companies from Group 4 acquired the majority of the assets of firms such as Verasun and Panda Ethanol after they filed for bankruptcy. Without significant upstream-related R\&Cs, Verasun, the most highprofile casualty, depended on hedging its feedstock supply, but this strategy turned out to be fatal when feedstock prices fell sharply at the onset of the crisis. Other casualties, such as Pacific Ethanol and Aventine, managed to re-emerge after restructuring.

\section{Taxonomy of pre-entry resources and capabilities}

The importance of pre-entry R\&Cs has also been demonstrated in a number of studies. For instance, Klepper and Simons (2000) argue that the pre-entry experience of a firm is valuable across many industries and will affect their performance and survival in a new industry. However, not all types of pre-entry R\&Cs are of equal importance. Previous studies suggest that firms have 'leveragable' assets of dynamic competencies (Teece and Pisano, 1994) or a bundle of skills and technologies (Hamel and Prahalad, 1994) when entering a new industry. But the question remains as to which critical pre-entry capabilities of a firm affect performance and ultimate survival. Some entrant's R\&Cs are crucial for survival, for example in the case of the biofuel sector, the capability to source feedstock, particularly at times of severe competition for feedstock and high price volatility, especially in a marketplace where relational factors are 
important, i.e., where trust and relationships must be built over time (Vangen and Huxham, 2003). Therefore, we suggest that core R\&Cs should be further classified as critical and noncritical in accordance with industry characteristics.

Previous studies, particularly those adopting a resource-based view, have classified the R\&Cs of firms according to a number of hierarchies or taxonomies. For example, Barney (1991) categorizes $\mathrm{R} \& \mathrm{C}$ into three types, i.e. physical, human, or organizational. Helfat and Lieberman (2002) provide a wide range of taxonomies, e.g., type of market entry opportunities, entrant type, mode of entry, core versus complementary R\&Cs, and specialized versus generalized R\&Cs. These approaches have primarily adopted the perspective of the entrant without considering the bundle of R\&Cs required to be competitive in the new industry. An agro-food commodity firm, for example, may enter the ethanol-manufacturing stage, bringing along a bundle of core and complementary R\&Cs. Complementary R\&Cs are typically common across many industries, such as finance, accounting, human resources, and administration (Helfat and Lieberman, 2002). Core R\&Cs are those specific to the industrial operations such as technological knowhow. However, within the subset of common R\&Cs, the core R\&Cs may not all be of equal importance. Which R\&Cs really matter to obtaining sustainable competitive advantage in the new industry? Other classification of R\&Cs related to industry- and marketdetermined factors is Strategic Industry Factors (SIF) suggested by Amit and Schoemaker (1993) on how best to secure organizational rents. These Strategic Industry Factors are context dependent, differing from industry to industry and may be transient or more persistent.

Any mismatch between the entrant's R\&Cs and the R\&Cs required in the new industry could compromise the competitiveness and survival of the entrant. Within every entrant's R\&Cs, there is a subset that is applicable to the new industry or overlapping with the required R\&Cs for the new industry. For instance, the agro-food commodity firm may have tacit knowledge of the 
feedstock market required in the ethanol manufacturing. Identifying the intersection of the entrant's pre-entry R\&Cs and the new industry's required $\mathrm{R} \& \mathrm{Cs}$ is an important task in the entry decision-making process. The entrant would be able to know their strengths and competitive advantages in the new industry. Moreover, the entrant could also identify the missing core R\&Cs required in the new industry and make decisions on how best to develop or acquire them.

We thereby propose to extend Helfat and Lieberman's (2002) taxonomy of R\&C, by focusing on 'critical' R\&Cs, which would satisfy the requirements laid out in the SIF framework. It is thereby important for a manager to fully evaluate their SIF prior to entry. Using ethanol manufacturing as an example, Table 2 illustrates a set of taxonomies of core versus complementary R\&Cs based on interviews conducted with industrial experts and stakeholders. Further, critical R\&Cs are those that are central to the competitiveness of the business and could be derived from the market- and industry-determined SIF.

\section{[Insert Table 2 here]}

In the case that the entrant does not own all the necessary critical R\&Cs to match the SIF, it should logically seek to develop or acquire them and answer several key questions before proceeding. Can these missing critical R\&Cs be easily developed within an acceptable timeframe before the entrant's competitiveness is compromised? Alternatively, if these missing critical R\&Cs are tradable, can they be acquired and absorbed within the organization in sufficient time post-entry? To reflect these challenges, we propose a further classification based on 'ease of acquisition'.

Table 3 summarizes the pre-entry R\&Cs of the five groups of entrants within the ethanol industry found in Table 1. For example, for Group 1 a requisite pre-entry capability in ethanol distillery process and operations is having a set of core R\&Cs useful in ensuring efficient operations. However, ensuring normal operations of the ethanol distillery is not considered a 
critical core $\mathrm{R} \& \mathrm{C}$ since it is commonly available, is rather mature and standardized and could be easily acquired.

By contrast, the pre-entry R\&Cs for Group 2 and Group 3 in the feedstock market are critical core R\&Cs since they match with the required SIF and are especially important in an illiquid market. The ability to manage farmers and suppliers of feedstock is important to the success of any manufacturer, as feedstock costs can account for $60 \%$ or more of total manufacturer costs (Sanchez and Cardona, 2008). In addition, access to feedstock is especially critical during periods of tight supply. This capability is particularly difficult to acquire in a relational feedstock market.

[Insert Table 3 here]

\section{Integration to seek out resources and capabilities}

By tracing the evolution of the bio-ethanol sector over two decades, we observe a phenomenon of bi-directional vertical integration, where firms predominantly operating in downstream stages have integrated upstream and vice versa, as shown in Table 4. We find forward integration of larger firms in Group 1 (Engineering), Group 2 (agro-food cultivators and processors) and Group 3 (agro-food commodity traders) when they entered into the stage of manufacturing utilizing their pre-entry R\&Cs as shown in Table 1. The strategic R\&C available to the firms could be utilized to gain long-term competitive advantage (Wernerfelt, 1984). For example, firms in Group 1 and Group 2 capitalized on their technological knowhow or knowledge of the feedstock supply, to develop a new line of businesses in an expanding ethanol market.

[Insert Table 4 here]

Moreover, several firms integrated further downstream into marketing, blending, distribution 
and retailing in order to secure markets for their products. Table 4 shows the progression of firms integrating downstream, particularly since 2005. In most countries, traditional petroleum firms dominate these downstream stages of the value chain. Although growing, ethanol volume remains relatively small compared to gasoline in the overall blending volume. As there is excess petroleum refining capacity in some parts of the world, refiners can be reluctant to pursue ethanol blending and often seek to erect barriers to government aspirations to mandate any blending. The organizational inertia of incumbents is well known in many other industries (Agarwal and Moeen, 2016), In order to reach retail markets, ethanol manufacturers must often be proactive and integrate into downstream stages, especially into higher blend markets (i.e., where higher percentages of ethanol are used in the gasoline blend) that might provide one solution to a more passive position towards marketing their products.

Another striking example is Cosan in Brazil, which has become the most vertically integrated ethanol firm in the world, occupying all stages along the sugarcane-based ethanol value chain after its acquisition of ExxonMobil's downstream operation in Brazil in 2008 (Table 4). Further, Raizen, formed by Cosan and Shell, has owned the fuel distribution and retail stages of both Cosan and Shell in Brazil since 2010. Cosan and Raizen hope for a more sustainable growth path than Verasun, which carried out the most spectacular downstream integration from 2003 to 2006. Before filing for bankruptcy, Verasun had become the largest ethanol manufacturer in the world, with eleven operational plants and six new plants under construction or under development. It blended and marketed its own brand of E85 ethanol to 150 retailing stations across 15 U.S. states. Other examples of such vertical integration includes GPRE acquiring Blendstar in 2008 to move into downstream blending and distribution markets, and Pacific Ethanol creating a marketing arm - Kinergy Fuel Marketing.

Table 4 and the discussion above offer some clear examples of forward integration of ethanol 
manufacturers. A number of de novo firms and upstream de alio firms have integrated further downstream to production stages such as marketing, blending, distribution and retail. Ethanol manufacturers appreciate that they should not depend on incumbent oil companies to market a substitute for their own product and will need to break through the monopolization of oil companies at downstream stages of the value chain.

As Perry (1988: 206) has suggested, one of the motivations for firms to employ vertical integration strategies is not only to secure the market for its product(s), but also to gain the ability to sell the quantity of output the firm wishes. This motivation to access the retail market appears to be critical in a market where incumbents control the marketing channels of the substitutes.

Three types of backward integration have also been observed in the ethanol sector over the period studied. First, firms in the downstream value chain - transportation fuel refining, distribution and retailing, have integrated upwards to include the ethanol-manufacturing segment. These firms are required to fulfill their regulatory obligations in selling ethanol in various jurisdictions and therefore move upstream to enhance the security of their ethanol supply. Securing ethanol supply is unlikely to be the sole motivation in markets where liquidity in ethanol trading is high. Other motivations for oil companies to move into ethanol manufacturing include improving brand identity, building a more environmental-friendlier image or seeking additional rents. It is notable though that no international oil company apart from Shell has made it to the top thirty in ethanol manufacturing despite their unmatchable financial capability. Nonetheless, some petroleum refiners, especially those without an upstream oil exploration business such as Valero and Flint Hills Resources, have diverted away from the increasingly low-margin refining segment and into ethanol manufacturing. 
The backward integration of oil firms into ethanol manufacturing and production of feedstock increased but only slowly over the period of study. This sluggishness was possibly due to inertia or a mismatch between the set of organizational skills required (Teece et al., 1997) for their conventional operations (in oil, especially upstream activities) and those needed for the new venture (in agro-business). Key differences include scale of investment, expectation of returns, lack of experience in agricultural commodity markets, agricultural management and social and political aspects of agricultural activities. Therefore, pre-entry $\mathrm{R} \& \mathrm{C}$ could also constrain a firm's decision to engage in vertical integration as proposed by Nelson and Winter (1982) and Jacobides et al. (2009).

Second, some ethanol manufacturers have integrated downstream into feedstock trading, and further into feedstock cultivation as well as land ownership. Manufacturers without any preentry $\mathrm{R} \& \mathrm{C}$ in feedstock supply have been inclined to integrate upstream to mitigate the risks of uncertainty in feedstock supply and price volatility. In the U.S., those manufacturers operating without a degree of upstream integration, e.g., de novo entrants, have been susceptible to high feedstock supply risks. In response, firms most exposed to such risks, such as Verasun, have sought to mitigate them. By contrast, the two leading U.S. ethanol manufacturers - ADM and POET - escaped a similar fate because they had a stronger degree of integration upstream in both trading and cultivation of maize. Firms, such as those in Group 2 and 3, with pre-entry experience in similar industries or supply chains, have demonstrated that they are more resilient, in agreement with the findings of Klepper and Simons (2000).

There is a tendency towards backward integration from manufacturing to farming/commodity trading, although this is less prevalent in certain regions, notably the U.S. The high liquidity in the U.S. feedstock market provides less incentive for integration. In addition, barriers to entry, including capital requirements, skills, and land acquisitions, can also be high since farm size is 
generally large. By contrast, a large number of Brazilian manufacturers own and lease land for cane cultivation due to favorable social-political and historical factors. There is also less backward integration of manufacturers in countries such as China, Thailand, Vietnam and the Philippines because of unfavorable macro-institutional factors.

We conclude with three observations about backward integration. First, firms without pre-entry R\&Cs would likely integrate downstream to ensure high security of feedstock supply, which is in line with resolving uncertainty and thereby reducing transaction costs (Williamson, 1996). Security of supply includes the ability to obtain the quantity of feedstock required at a stable and desirable price, since ethanol manufacturers are mostly price takers in the feedstock market. A similar phenomenon can be found in the oil industry's move upstream to secure oil reserves (Buzzell, 1983).

Second, there are notable exceptions in downstream integration, particularly in certain markets, where institutional forces might undermine attempts to integrate further upstream (such as into cultivation stages). For example, in the case where there are a large number of small family farms at the cultivation stage, and there is political sensitivity and even legal prohibitions on land ownership by large corporations and foreigners, such as in China, Thailand and Vietnam.

The third type of backward integration is the integration of ethanol manufacturers into the engineering and technology stage based on a motivation to enhance economies of scope. In the U.S. for instance, both POET and ADM have the capability to design and build distilleries. A newcomer at this stage is Shree Renuka of India - a sugar-ethanol company with operating units in India and Brazil. In 2007, it acquired KBK, an engineering and construction company based in India, which builds distilleries throughout Asia. 


\section{Theoretical and practical implications}

This study attempts to understand industrial life cycles at their early stages. By mapping out the development of the bio-ethanol sector, we conclude that new entrants need to understand their pre-entry $\mathrm{R} \& \mathrm{Cs}$ and how those match with the critical $\mathrm{R} \& \mathrm{Cs}$ required to survive in their new industry. First, we propose that the R\&Cs of new entrants should be classified as either critical or non-critical. Many very successful biofuel firms belong to the de alio group. A de novo firm's survival rate is expected to be lower than that of a de alio firm as suggested by other studies such as Geroski (1995) and Helfat and Lieberman (2002), which has led to the 'dominance by birthright' theory propounded by Klepper and Simons (2000). Successful de alio firms have been shown to leverage their critical pre-entry R\&Cs when entering into the biofuel market. Experience increases the value of entry and encourages entry into new markets, as found in King and Tucci (2002). However, not all pre-entry R\&Cs are equally important. Therefore, we need to classify them in terms of their criticality to the performance and survival of the entrant, which are context specific to an industry or market.

A further classification of entrant's R\&Cs in terms of 'ease of acquisition' is also proposed - if any R\&Cs could be easily acquired within a short period of time, the competitive advantage of de alio firms would diminish rapidly. Similarly, entrants, even those that have grown into sizable firms, may fail because of their inability to build the critical R\&Cs in time. Thus, a key post-entry strategy is to identify and acquire critical R\&Cs, which an entrant has yet to control.

Therefore, we observe that biofuel firms integrate further up or down along the value chain in order to acquire new R\&Cs, since they will be critical for their survival and growth in the new industry. We propose that de novo entrepreneurial firms in a rapidly evolving green sector need to quickly identify critical R\&Cs in their industry and strategize to acquire and control them in order to survive and growth. Through waves of acquisition and shifting control over critical 
R\&Cs, the evolution of the biofuel industry demonstrates a consistent phenomenon of bidirectional vertical integration.

The motivations for vertical integration could be explained by resources-driven integration (Eschen and Bresser, 2005) with the intention of avoiding uncertainty as proposed in Transaction Cost Theory (Williamson, 1975). It is also consistent with the findings of a recent study of the U.S. brewing industry (Walter et al., 2016) where firms actively deployed strategic choice (Short and Payne, 2008) to develop the necessary capabilities to avoid being shaken out. Kapoor (2018) has also demonstrated the persistence of semiconductor industry to integrate vertically despite the waves of specialization. In conclusions, similar to Helfat (2015), we find that the evolution towards greater vertical integration depends on the needs to control critical R\&Cs, which are context specific.

In addition, our study also suggests that a firm's prior experience could impose constraints on post-entry strategic choice of vertical structure, building on studies such as Nelson and Winter (1982) and Jacobides et al. (2009). For example, we can see the reluctance of incumbent firms (i.e. oil companies) to invest in biofuel manufacturing, which included an unfamiliar upstream sector (agriculture) with low returns (at least compared to traditional petroleum).

\section{Limitations and future work}

Finally, there are two aspects that we do not consider here and would therefore recommend for future study. We do not assess the interaction between institutional factors and a firm's stakeholders in influencing or facilitating strategic movements along the value chain. We also do not take into consideration the implications of advanced technological development in the biofuels sector, which although negligible over the period of our study, could be revolutionary in changing the configuration and governance of the value chain in the future. For instance, three commercial-scale cellulosic ethanol facilities with a combined capacity of 284 million 
liters have begun production in the U.S. in 2015 (RFA, 2016).

There are a number of other nascent 'green' industries, which would benefit from a similar treatment. Offshore wind and solar photovoltaic panels (which has similar characteristics of a commoditized technology with firms entering from adjacent sectors) or bio-plastics derived from agricultural materials are obvious parallels. Still other even newer industries, such as those involving the Internet of Things, are probably at too early a stage to provide sufficient evidence, but they may be fruitful areas to explore within a few years. Evidence from other sectors could reinforce or expand our understanding of firm survival.

\section{References:}

Amit, R. and Schoemaker, P.J.H. (1993), "Strategic assets and organizational rent", Strategic Management Journal, Vol. 14, pp. 33-46.

Agarwal, R. and Moeen, M. (2016), "Entrepreneurial startups (de novo), diversifying entrants (de alio) and incumbent firms", In Augier, M. and Teece, D. (eds), Palgrave Encyclopedia of Strategic Management, Palgrave Macmillan, London.

Barnett, W.P. and Carroll, G.R. (1995), "Modeling internal organizational change", Annual Review of Sociology, Vol. 21, pp. 217-236.

Barney, J.B. (1991), "Firm resources and sustained competitive advantage", Journal of Management, Vol. 17 No. 1, pp. 99-120.

Bellone, F., Musso, P., Nesta, L. and Quere, M. (2008), "Market selection along the firm life cycle", Industrial and Corporate Change, Vol. 17 No. 4, pp. 753-777.

BP (2018), BP Statistical Review of World Energy, $67^{\text {th }}$ edition. BP Plc.

Buenstorf, G. (2007), "Evolution on the shoulders of giants: entrepreneurship and firm survival in the German laser industry", Review of Industrial Organization, Vol. 30, pp. 179-202.

Buzzell, R.D. (1983), "Is vertical integration profitable", Harvard Business Review, Vol. 61 No. 1, pp. 92-102.

Carroll, G.R., Bigelow, L.S., Seidel, M-DL. and Tsai, L.B. (1996), "The fates of de novo and de alio producers in the American automobile industry 1885-1981", Strategic Management Journal, Vol. 17, pp. 117-137.

Chen, X. and Wang, X. (2017), "Achieve a low carbon supply chain through product mix", Industrial Management \& Data Systems, Vol. 117 Issue: 10, pp. 2468-2484.

Chen, P.L., Williams, C. and Agarwal, R. (2012), "Growing pains: Pre-entry experience and the challenge of transition to incumbency", Strategic Management Journal, Vol. 12 No. 1, pp. 252-276.

Coase, R. (1937), "The Nature of the Firm", Economica, Vol. 4, pp. 386-405.

de Silva DG, Hubbard TP, McComb RP, Schiller AR. 2017. Entry, growth and survival in the green industry. Regional Studies 51(12): 1774-1785. 
Eisenhardt, K.M. (1989), "Agency Theory: An Assessment and Review", Academy of Management Review, Vol. 14 No. 1, pp. 57-74.

Energy Information Administration (EIA) (2013), International Energy Statistics (Energy Information Administration, the USA Department of Energy, Washington DC). Last accessed 15 December 2013.

Eschen, E. and Bresser, R.K. (2005), "Closing resource gaps: toward a resource-based theory of advantageous mergers and acquisitions", European Management Review, Vol. 2 No. 3, pp. 167-178.

Finney, R.Z., Lueg, J.E. and Campbell, N.D. (2008), "Market pioneers, late movers, and the resource-based view (RBV): A conceptual model", Journal of Business Research, Vol. 61 No. 9, pp. 925-932.

FO Licht (2012), World Ethanol and Biofuels Report, Vol. 10 No. 16, 24 April.

Ganco, M. and Agarwal, R. (2009), "Performance differentials between diversifying entrants and entrepreneurial start-ups", Academy of Management Review, Vol. 34 No. 2, pp. 228252.

Geels, F.W. (2010), "Ontologies, socio-technical transitions (to sustainability), and the multilevel perspective", Research Policy, Vol. 39 No. 4, pp. 495-510.

Gereffi, G., Humphrey, J. and Sturgeon, T. (2005), "The Governance of Global Value Chains: An Analytic Framework", Review of International Political Economy, Vol. 12 No. 1, pp. 78-104.

Geroski, P.A. (1995), "What do we know about entry?", International Journal of Industrial Organization, Vol. 13 No. 4, pp. 421-440.

Gibbon, P. and Ponte, S. (2005), Trading Down: Africa, Value Chains, and the Global Economy. Philadelphia: Temple University Press.

Global Agriculture Information Network Report (GAIN) (2012), Brazil Biofuels Annual Report BR12012. Department of Agriculture: Washington DC.

Gomez, J., Lanzolla, G. and Maicas, J.P. (2016), "The role of industry dynamics in the persistence of first mover advantages", Long Range Planning, Vol. 49 No. 2, pp. 265281.

Hamel, G. and Prahalad, C.K. (1994), Competing for the future. Harvard Business School Press: Boston.

Haveman, H.A. (1992), "Between a rock and a hard place: Organizational change and performance under conditions of fundamental environmental transformation", Administrative Science Quarterly, Vol. 37, pp. 48-75.

Helfat, C.E. (2015), "Vertical firm structure and industry evolution", Industry and Corporate Change, Vol. 24 No. 4, pp. 803-818.

Helfat, C.E. and Lieberman, L.B. (2002), "The birth of capabilities: market entry and importance of pre-history" Industry and Corporate Change, Vol. 11 No. 4, pp. 725-760.

Helfat, C.E. and Campo-Rembado, M.A. (2016), "Integrative capabilities, vertical integration, and innovation over successive technology lifecycles", Organization Science, Vol. 27 No.2, pp. 249-264.

Helfat, C.E. and Peteraf, M.A. (2003), "The dynamic resource-based view: Capability lifecycles", Strategic Management Journal, Vol. 24 No. 10, pp. 997-1010.

Huberman, A.M. and Miles, M.B. (1994), Qualitative Data Analysis: An Expanded Sourcebook ( $2^{\text {nd }}$ ed.). Sage: London. 
International Energy Agency (IEA) (2011), Technology roadmap: Biofuels for transport International Energy Agency. Available at http://www.iea.org/papers/2011/biofuels_roadmap.pdf

Jacobides, M.G. (2005), "Industry change through vertical disintegration: How and why markets emerged in mortgage banking", Academy of Management Journal, Vol. 48 No. 3, pp. 465-498.

Jacobides, M.G., Brusconi, S. and Prencipe, A. (2009), "Strategic Dynamics in industry architectures and the challenges of knowledge integration", European Management Review, Vol. 6 No. 4, pp. 209-216.

Kagut, B. and Zander, U. (1992), "Knowledge of the firm, combinative capabilities, and the replication of technology", Organization Science, Vol. 3 No. 3, pp. 383-397.

Kapoor, R. (2013), "Persistence of integration in the face of specialization: How firms navigated the winds of disintegration and shaped the architecture of the semiconductor industry", Organization Science, Vol. 24 No. 4, pp. 1195-1213.

Kim, B. and Park, K. (2006), "Dynamics of industry consolidation and sustainable competitive strategy: Is birthright irrevocable?" Long Range Planning, Vol. 9 No. 5: pp. 543-566.

King, A. and Tucci, C. (2002), "Incumbent entry into new market niches: the role of experience and managerial choice in the creation of dynamic capabilities", Management Science, Vol. 48 No. 2, pp. 171-186.

Klepper, S. (2002a), "The capabilities of new firms and the evolution of the US automobile industry", Industrial and Corporate Change, Vol. 11 No. 4, pp. 645-666.

Klepper, S. (2002b), "Firm survival and the evolution of oligopoly", Journal of Economic, Vol. 33 No. 1, pp. 37-61.

Klepper, S. and Simons, K.L. (2000), "Dominance by birthright: entry of prior radio producers and competitive ramifications in the U.S. Television Receiver Industry", Strategic Management Journal, Vol. 21, pp. 997-1016.

Klepper, S. and Sleeper, S. (2005), "Entry by spinoffs", Management Science, Vol. 51 No. 8, pp. 1291-1306.

Knudsen, T., Levinthal, D.A. and Winter, S.G. (2014), "Hidden but in plain sight: The role of scale adjustment in industry dynamics", Strategic Management Journal, Vol. 35, pp. 1569-1584.

Mingo, S. and Khanna, T. (2013), "Industrial policy and the creation of new industries: evidence from Brazil's bioethanol industry", Industrial and Corporate Change, Vol. 23 No. 5, pp. 1229-1260.

Moeen, M. (2017), "Entry into nascent industries: disentangling a firm's capability portfolio at the time of investment versus market entry", Strategic Management Journal, Vol. 38 No. 10, pp. 1986-2004.

Nelson, R.R. and Winter, S.G. (1982), An evolutionary theory of economic change. Belknap Press: Cambridge, MA.

Penrose, E.T. (1959), The theory of the growth of the firm. Wiley: New York.

Perry, M.K. (1988), "Vertical integration", In R. Schmalensee and R.D. Wilig (Eds). Handbook of Industrial Organization, Vol. 1, Elsevier Science: Amsterdam.

POET (2013), POET History. Available at http://poet.com/history. Last accessed: 30 January 2013. 
Qian, L., Agarwal, R. and Hoetker, G. (2012), "Configuration of value chain activities: The effect of pre-entry capabilities transaction hazards, and industry evolution on decisioins to internalize", Organization Science, Vol. 23 No. 5, pp. 1330-1349.

Raizen. 2013. Our energy generates a better future. Raizen. Available at http://www.raizen.com/en/raizen/quem-somos.aspx. Last accessed: 30 January 2013.

Riordan, M.H. (2008) "Competitive effects of vertical integration", In P. Buccirossi (ed.) Handbook of antitrust economics, MIT Press: Cambridge, MA. 145

Renewable Fuels Association (RFA) (2013), Global ethanol production statistics. http://www.ethanolrfa.org/resources/industry/statistics/\#1454098996479-8715d404e546. Last accessed: 01 October 2016.

Renewable Fuels Association (RFA) (2016), Annual industry outlook. Washington, DC.

Roberts, P.W., Klepper, S. and Hayward, S. (2011), "Founder backgrounds and the evolution of firm size", Industrial and Corporate Change, Vol. 20 No. 6, pp. 1515-1538.

Sanchez, O.J. and Cardona, C.A. (2008), "Trends in biotechnological production of fuel ethanol from different feedstocks", Bioresource Technology, Vol. 99 No. 13, pp. 5270-5295.

Shepherd, D.A. and de Tienne, D.R. (2004), "Prior knowledge, potential financial reward, and opportunity identification", Entrepreneurship Theory and Practice, Vol. 29 No. 1, pp. 91-112.

Short, J.C. and Payne, G.T. (2008), "First movers and performance: Timing is everything", Academy of Management Review, Vol. 33 No. 1, pp. 267-269.

Stigler, G.J. (1951), "The Division of Labor Is Limited by the Extent of the Market", Journal of Political Economy, Vol. 59, pp. 185-93.

Stuckey, A. (1983), Vertical integration and joint ventures in the aluminum industry, Cambridge, MA: Harvard University Press.

Teece, D.J. and Pisano, G. (1994), "The dynamic capabilities of firms: an introduction", Industrial and Corporate Change, Vol. 3, pp. 537-556.

Teece, D.J., Pisano, G. and Shuen, A. (1997), "Dynamic capabilities and strategic management", Strategic Management Journal, Vol. 18 No. 7, pp. 509-533.

Thompson, P. (2005), "Selection and firm survival: evidence from the shipbuilding industry, 1825-1914", Review of Economics and Statistics, Vol. 87 No. 1, pp. 26-36.

UNICA (2010), Quotes and stats. Available at http://english.unica.com.br/dadosCotacao/estatistica/. Last accessed 20 March 2012.

Uzunca, B. (2018), "A Competence-Based View of Industry Evolution: The Impact of Submarket Convergence on Incumbent- Entrant Dynamics", Academy of Management Journal, Vol. 61 No. 2, pp. 738-768.

Vangen, S. and Huxham, C. (2003), "Nurturing collaborative relation: Building trust in interorganizational collaboration", Journal of Applied Behavioral Science, Vol. 39 No. 1, pp. 5-31.

Vidal, E. and Mitchell, W. (2013), "When do first entrants become first survivors?", Long Range Planning, Vol. 46 No. 4, pp. 335-347.

Walter, L.A., Edelman, L.F. and Hatten, K.J. (2014), "The US brewing industry, strategic windows and survival", Journal of Management History, Vol. 20 No. 4, pp. 434-458.

Walter, L.A., Edelman, L.F. and Hatten, K.J. (2016), "Early entry, capabilities and shakeout in the US brewing industry", Journal of Management History, Vol. 22 No.1, pp. 24-49.

Wernerfelt, B. (1984), "A Resource-based view of the firm", Strategic Management Journal, Vol. 5, pp. 171-180. 
Wiesenthal, T., Leduc, G., Christidis, P., Schade, B., Pelkmans, L., Govaerts, L. and Georgopoulos, P. (2009), "Biofuel support policies in Europe: lessons learnt for the long way ahead", Renewable and Sustainable Energy Reviews, Vol. 13, pp. 789-800.

Williamson, O.E. (1975), Markets and Hierarchies: Analysis and Antitrust Implications. Free Press: New York.

Williamson, O.E. (1985), The Economic Institutions of Capitalism. New York: Free Press.

Williamson, O.E. (1996), The Mechanisms of Governance. Oxford University Press: Oxford.

Ye, F., Hou, G., Li, Y. and Fu, S. (2018), "Managing bioethanol supply chain resiliency: a risksharing model to mitigate yield uncertainty risk", Industrial Management \& Data Systems, Vol. 118 No. 7, pp. 1510-1527. 
Table 1: Industry of origin - Global top-thirty ethanol manufacturers as of end of 2012

\begin{tabular}{|c|c|c|c|c|}
\hline Group & $\begin{array}{c}\text { Type of entrant - } \\
\text { industry of } \\
\text { origin }\end{array}$ & Description & Manufacturers & $\begin{array}{l}\text { Global } \\
\text { rank }\end{array}$ \\
\hline 1 & \multirow{3}{*}{$\begin{array}{l}\text { De alio - } \\
\text { Engineering }\end{array}$} & \multirow{3}{*}{$\begin{array}{l}\text { Technical \& } \\
\text { engineering industry } \\
\text { background }\end{array}$} & POET & 2 \\
\hline & & & Abengoa Bioenergy & 4 \\
\hline & & & ETH Bioenergia & 5 \\
\hline \multirow{9}{*}{2} & \multirow{9}{*}{ De alio - Farming } & \multirow{9}{*}{$\begin{array}{l}\text { Farmer and farmer } \\
\text { cooperatives and agro- } \\
\text { food and sweetener } \\
\text { manufacturers. These } \\
\text { firms have a long } \\
\text { history in food/ } \\
\text { sweetener, and some in } \\
\text { alcohol production too }\end{array}$} & Cosan-Raizen* & 7 \\
\hline & & & Guardian Energy & 10 \\
\hline & & & Tereos - Guarani & 13 \\
\hline & & & Shree Renuka & 15 \\
\hline & & & Big River Resources & 16 \\
\hline & & & Jilin Alcohol & 18 \\
\hline & & & TianGuan & 26 \\
\hline & & & Sao Martinho - Nova Fontiera & 20 \\
\hline & & & Greenfield Ethanol & 29 \\
\hline \multirow[t]{8}{*}{3} & \multirow{8}{*}{$\begin{array}{l}\text { De alio - Agro- } \\
\text { food commodity } \\
\text { trading }\end{array}$} & \multirow{8}{*}{$\begin{array}{l}\text { Main activities are } \\
\text { sourcing or marketing } \\
\text { agricultural } \\
\text { commodities. Some } \\
\text { have diversified and } \\
\text { also involved in food } \\
\text { processing industry }\end{array}$} & ADM & 1 \\
\hline & & & Louis Dreyfus & 8 \\
\hline & & & Cargill & 11 \\
\hline & & & Bunge & 14 \\
\hline & & & $\mathrm{COFCO}$ & 17 \\
\hline & & & The Andersons Group & 19 \\
\hline & & & Noble Group & 22 \\
\hline & & & Marquis Energy & 27 \\
\hline \multirow[t]{6}{*}{4} & \multirow{6}{*}{$\begin{array}{l}\text { De alio - Oil and } \\
\text { gas }\end{array}$} & \multirow{6}{*}{$\begin{array}{l}\text { Oil and gas firms and } \\
\text { downstream marketers } \\
\text { of motor gasoline }\end{array}$} & Valero RF. & 3 \\
\hline & & & Shell - Raizen* & 7 \\
\hline & & & Flint Hills Resources & 9 \\
\hline & & & Murphy Oil & 25 \\
\hline & & & CNPC & 30 \\
\hline & & & Petrobras-Guarani, N Frontiera $* *$ & $13 ; 20$ \\
\hline \multirow[t]{6}{*}{5} & \multirow[t]{6}{*}{ De novo } & \multirow{6}{*}{$\begin{array}{l}\text { Entrepreneurial spin- } \\
\text { offs and start-ups with } \\
\text { little or no background } \\
\text { in the biofuel supply } \\
\text { chain }\end{array}$} & Green Plains Renewable Energy & 6 \\
\hline & & & Aventine Renewable Energy*** & 12 \\
\hline & & & White Energy & 21 \\
\hline & & & BioFuel Energy & 23 \\
\hline & & & Pacific Ethanol & 24 \\
\hline & & & Glacial Lakes Energy & 28 \\
\hline
\end{tabular}

Sources: Company websites

Note: $\quad *$ For Raizen, its parent companies, Cosan and Shell, were considered separately (Raizen, 2013).

**Petrobras holds a substantial stake in both Guarani and Nova Frontiera Bioenergy, but does not have a controlling interest.

***Aventine Renewable Energy was merged with Pacific Ethanol in July 2015 demonstrating the continuing evolution of the industry in both expanding scope and scale. 
Table 3: Taxonomy of resources and capabilities: Ease of acquisition of critical R\&C

\begin{tabular}{|l|l|l|l|}
\hline \multicolumn{1}{|c|}{ Type of entrant } & \multicolumn{1}{|c|}{ Core pre-entry R\&C } & \multicolumn{1}{c|}{ Critical R\&C } & \multicolumn{1}{c|}{ Ease of acquisition } \\
\hline $\begin{array}{l}\text { Group 1: Technology, } \\
\text { cngineering and } \\
\text { construction firms }\end{array}$ & $\begin{array}{l}\text { Process and operations } \\
\text { knowledge }\end{array}$ & $\begin{array}{l}\text { Not critical, but it could } \\
\text { be significant if advanced } \\
\text { technology is developed }\end{array}$ & $\begin{array}{l}\text { Easy to acquire to a } \\
\text { satisfactory degree }\end{array}$ \\
\hline $\begin{array}{l}\text { Group 2: Farmer/farm } \\
\text { cooperatives and agro-food } \\
\text { manufacturers }\end{array}$ & $\begin{array}{l}\text { Familiarity with feedstock } \\
\text { market and control of } \\
\text { supply, insurance and risk } \\
\text { management }\end{array}$ & $\begin{array}{l}\text { Highly critical at times of } \\
\text { scarcity and high volatility }\end{array}$ & $\begin{array}{l}\text { Takes a long time to } \\
\text { acquire }\end{array}$ \\
\hline $\begin{array}{l}\text { Group 3: Agricultural } \\
\text { commodities traders }\end{array}$ & $\begin{array}{l}\text { Familiarity with feedstock } \\
\text { market, access to credit, } \\
\text { insurance, and risk } \\
\text { management }\end{array}$ & $\begin{array}{l}\text { Highly critical at times of } \\
\text { scarcity and high volatility }\end{array}$ & $\begin{array}{l}\text { Takes a long time to } \\
\text { acquire }\end{array}$ \\
\hline $\begin{array}{l}\text { Group 4: Traditional } \\
\text { petroleum firms and } \\
\text { downstream marketers }\end{array}$ & $\begin{array}{l}\text { Knowhow in blendstock } \\
\text { and additives, control } \\
\text { downstream supply chain }\end{array}$ & $\begin{array}{l}\text { Critical in controlling } \\
\text { downstream market } \\
\text { access }\end{array}$ & $\begin{array}{l}\text { Could be acquired but } \\
\text { need capital to build } \\
\text { infrastructure }\end{array}$ \\
\hline $\begin{array}{l}\text { Group 5: De novo } \\
\text { entrepreneurial start-ups }\end{array}$ & $\begin{array}{l}\text { Dynamic and } \\
\text { entrepreneurial }\end{array}$ & $\begin{array}{l}\text { Not critical but important } \\
\text { for long-term growth }\end{array}$ & $\begin{array}{l}\text { Could be acquired or } \\
\text { developed but not a } \\
\text { critical R\&C }\end{array}$ \\
\hline
\end{tabular}

Sources: Authors, based on interviews and analysis of expert's opinions.

Table 2: Taxonomy of resources and capabilities: Critical R\&C of ethanol manufacturers

\begin{tabular}{|c|c|c|}
\hline \multicolumn{3}{|c|}{ Core versus complementary resources and capabilities $(\mathrm{R} \& \mathrm{C})$} \\
\hline \multicolumn{2}{|c|}{ Core } & \multirow[t]{2}{*}{ Complementary } \\
\hline Critical & Non-critical & \\
\hline $\begin{array}{l}\text { Specialised R\&C core to } \\
\text { operations that match the } \\
\text { requirements of SIF, e.g.: } \\
\text { - Feedstock markets and pricing } \\
\text { knowledge } \\
\text { - Relationships with feedstock } \\
\text { suppliers } \\
\text { - Fuel markets and pricing } \\
\text { knowledge }\end{array}$ & $\begin{array}{l}\text { Specialised R\&C core to } \\
\text { operations, e.g.: } \\
\text { - } \quad \text { Plant operations } \\
\text { - Logistics and distribution } \\
\text { - Local and country-level } \\
\text { knowledge/policy } \\
\text { - Co-products markets and } \\
\text { pricing knowledge }\end{array}$ & $\begin{array}{l}\text { Supporting general R\&C needed } \\
\text { to ensure smooth operation in the } \\
\text { new industry, e.g.: } \\
\text { - } \quad \text { Finance and accounting } \\
\text { - } \quad \text { Administration and HR } \\
\text { - } \quad \text { Engineering } \\
\text { - } \quad \text { R\&D (short to medium term) }\end{array}$ \\
\hline
\end{tabular}

Sources: Authors, based on interviews and analysis of expert opinions. 
Table 4: Examples of bi-directional vertical integration in bioethanol sector

\begin{tabular}{|c|c|c|c|c|c|c|c|c|}
\hline \multirow[b]{2}{*}{$\begin{array}{c}2013 \\
\text { Global } \\
\text { Rank } \\
\end{array}$} & \multirow[b]{2}{*}{ Firm (Country) } & \multicolumn{2}{|c|}{ Upstream } & \multicolumn{2}{|c|}{ Midstream } & \multicolumn{3}{|c|}{ Downstream } \\
\hline & & $\begin{array}{l}\text { Plant- } \\
\text { ation }\end{array}$ & $\begin{array}{l}\text { Agro- } \\
\text { food / } \\
\text { service }\end{array}$ & $\begin{array}{l}\text { Ethanol } \\
\text { Manu- } \\
\text { facture }\end{array}$ & $\begin{array}{l}\text { Market- } \\
\text { ing }\end{array}$ & $\begin{array}{c}\text { Refine/ } \\
\text { Blend }\end{array}$ & Wholesale & Retail \\
\hline 4 & Abengoa (Spain) & $*$ & $*$ & 2000 & 2003 & 2007 & 2007 & \\
\hline 7 & Cosan (Brazil) & $\sim 1986$ & $\sim 1936$ & $\sim 1970$ & $*$ & 2008 & 2008 & 2008 \\
\hline 6 & GPRE (US) & & 2007 & 2007 & 2007 & 2008 & 2008 & \\
\hline 22 & $\begin{array}{l}\text { Noble (Hong } \\
\text { Kong) }\end{array}$ & 2007 & 1994 & 2007 & 2007 & & & \\
\hline 7 & $\begin{array}{l}\text { Shell } \\
\text { (Netherlands) }\end{array}$ & & 2010 & 2010 & $*$ & & & \\
\hline $13 / 20$ & Petrobras (Brazil) & 2010 & 2010 & 2010 & $*$ & & & \\
\hline N/A & Verasun, US & & & 2003 & 2005 & 2005 & 2006 & \\
\hline
\end{tabular}

Source: Data from manufacturers' websites, industry reports and market news reports.

Notes:

i) Shaded cell(s) indicate the firm's industry(ies) of origin.

ii) 'Year' or '*' denotes a new position (stage) occupied by the firm and the corresponding year of integration into that specific stage of production along the value chain.

iii) * - Data not available.

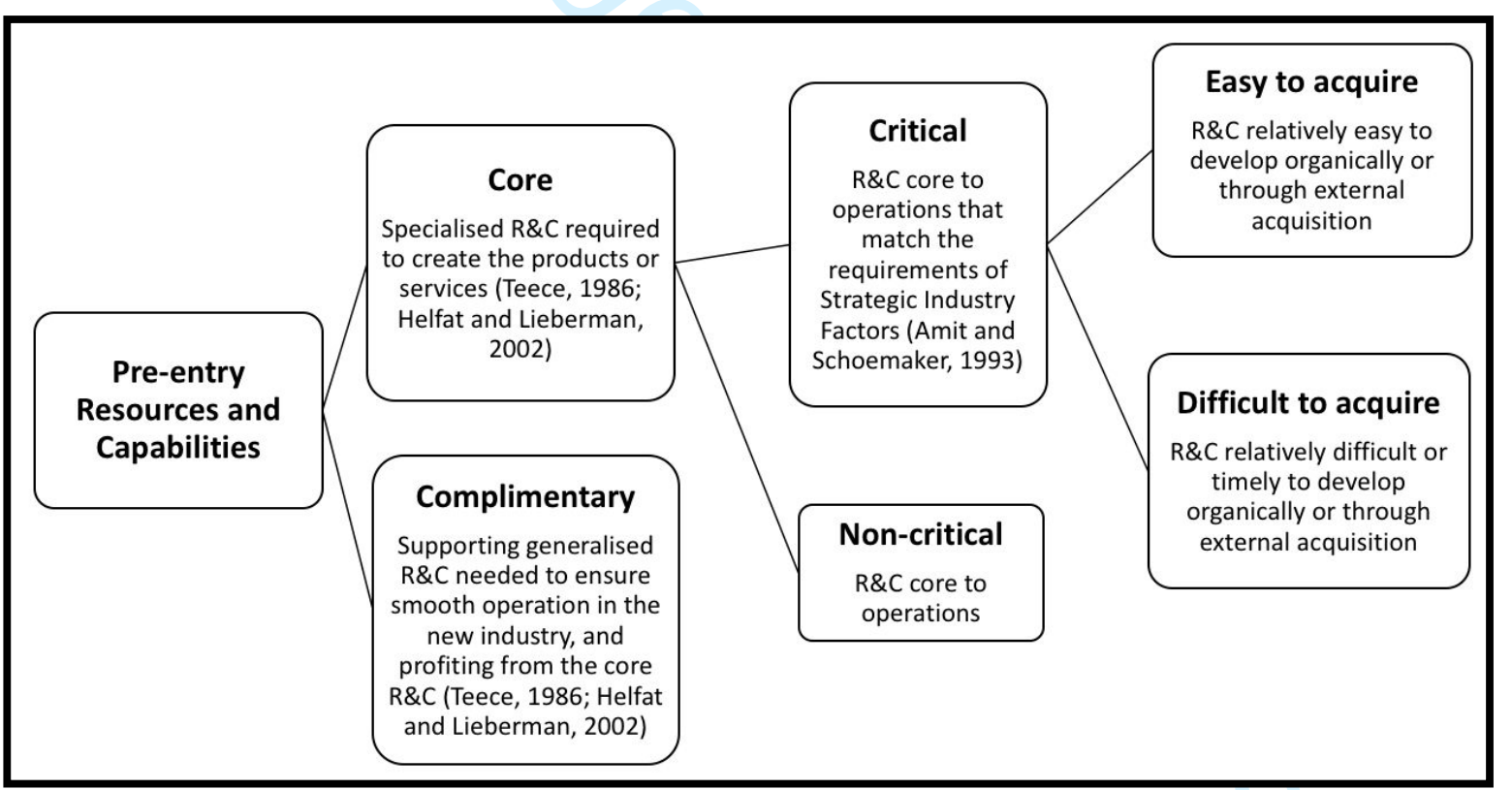

Figure 1: Proposed taxonomic structure for pre-entry resources and capabilities. 


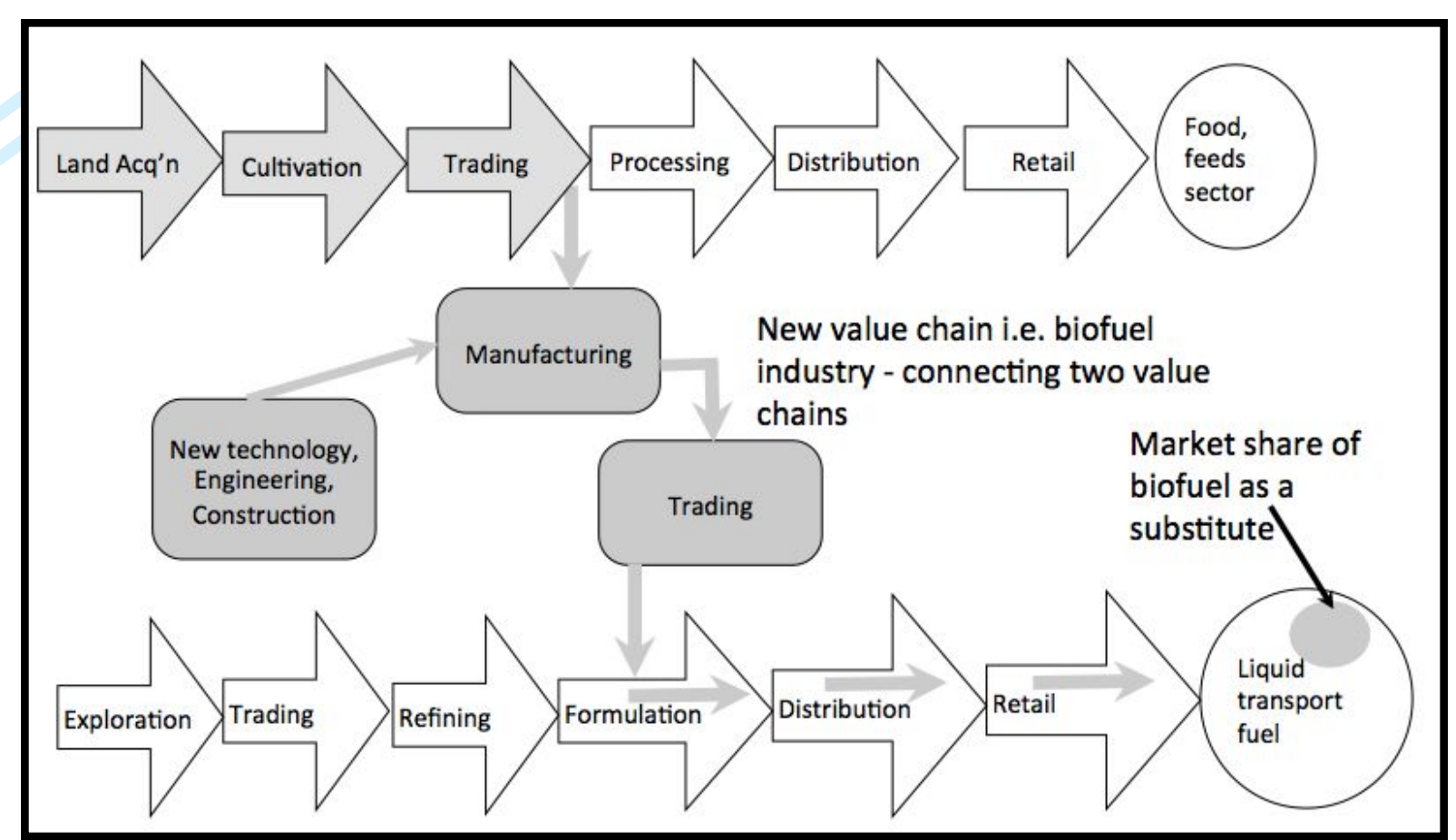

Figure 2: Fuel-ethanol value chain: a crossover of agro-food commodity to energy Note: Shaded stages represent fuel-ethanol value chain. Produced by the authors. 
Appendix A: Top-thirty global manufacturers and market shares, as of end of 2012

\begin{tabular}{|c|c|c|c|c|c|}
\hline $\begin{array}{l}\text { Global } \\
\text { Rank }\end{array}$ & Company & $\begin{array}{c}\text { Main operating } \\
\text { country } \\
\text { (HQ) } \\
\end{array}$ & $\begin{array}{c}\text { Global } \\
\text { share \% }\end{array}$ & $\begin{array}{c}\text { Country } \\
\text { share } \\
\text { (U.S.) } \% \\
\end{array}$ & $\begin{array}{c}\text { Country } \\
\text { share } \\
\text { (Brazil) \% }\end{array}$ \\
\hline 1 & Archer Daniels Midland & U.S., Brazil (U.S.) & 5.7 & 12.6 & - \\
\hline 2 & POET & U.S. & 4.7 & 10.6 & - \\
\hline 3 & Valero Renewable Fuels & U.S. & 3.2 & 7.3 & - \\
\hline 4 & Abengoa Bioenergy Corp & $\begin{array}{l}\text { Europe, U.S., } \\
\text { Brazil (Spain) }\end{array}$ & 3.2 & 2.6 & 0.6 \\
\hline 5 & ETH Bioenergia & Brazil & 2.3 & - & 7.0 \\
\hline 6 & $\begin{array}{l}\text { Green Plains Renewable } \\
\text { Energy (GPRE) }\end{array}$ & U.S. & 2.1 & 4.7 & - \\
\hline 7 & Raizen (Cosan \& Shell) & Brazil & 1.9 & - & 5.8 \\
\hline 8 & Louis Dreyfus/Santelisa Vale & $\begin{array}{l}\text { Brazil, U.S. } \\
\text { (Netherlands) }\end{array}$ & 1.8 & - & 4.2 \\
\hline 9 & Flint Hills Resources & U.S. & 1.6 & 3.6 & - \\
\hline 10 & Guardian Energy (\& alliances) & U.S. & 1.6 & 3.6 & - \\
\hline 11 & Cargill Inc & $\begin{array}{l}\text { U.S., Brazil, } \\
\text { Europe (U.S.) }\end{array}$ & 1.4 & 2.2 & - \\
\hline 12 & Aventine Renewable Energy & U.S. & 1.3 & 3.1 & - \\
\hline 13 & Guarani (Tereos \& Petrobras) & $\begin{array}{l}\text { Europe, Brazil } \\
\text { (France) }\end{array}$ & 1.3 & - & 2.0 \\
\hline 14 & Bunge/Moema & $\begin{array}{l}\text { Brazil, U.S. } \\
\text { (U.S.) }\end{array}$ & 1.3 & 1.1 & 2.6 \\
\hline 15 & Shree Renuka/Equipav & $\begin{array}{l}\text { Brazil, India } \\
\text { (India) }\end{array}$ & 1.3 & - & 3.4 \\
\hline 16 & Big River Resources LLC & U.S. & 1.0 & 2.3 & - \\
\hline 17 & $\mathrm{COFCO}$ & China & 1.0 & - & - \\
\hline 18 & Jilin Province Alcohol Ind. & China & 0.9 & - & - \\
\hline 19 & The Andersons Ethanol LLC & U.S. & 0.9 & 2.1 & - \\
\hline 20 & $\begin{array}{l}\text { Nova Frontiera Bioenergy } \\
\text { (Sao Martinho \& Petrobras) }\end{array}$ & Brazil & 0.8 & & \\
\hline 21 & White Energy & U.S. & 0.7 & 1.7 & - \\
\hline 22 & Noble Group & $\begin{array}{l}\text { Brazil, U.S. } \\
\text { (Hong Kong) }\end{array}$ & 0.7 & - & 1.9 \\
\hline 23 & BioFuel Energy LLC & U.S. & 0.7 & 1.5 & - \\
\hline 24 & Pacific Ethanol & U.S. & 0.7 & 1.5 & - \\
\hline 25 & Murphy Oil & U.S. & 0.6 & 1.5 & - \\
\hline 26 & TianGuan & China & 0.6 & - & - \\
\hline 27 & Marquis Energy LLC & U.S. & 0.6 & 1.4 & - \\
\hline 28 & Glacial Lakes Energy LLC & U.S. & 0.6 & 1.3 & - \\
\hline 29 & Greenfield Ethanol & Canada & 0.5 & - & - \\
\hline 30 & CNPC (Jilin Fuel Ethanol) & China & 0.5 & - & - \\
\hline
\end{tabular}

Note: (1) Includes plant capacity under construction and plants with significant minority stake. Total world capacity is estimated at 132 billion litres $(\mathrm{U} . \mathrm{S} .=58 \mathrm{~B}$; Brazil $=43 \mathrm{~B}$; rest of world $=31 \mathrm{~B}$ )

(2) '-' = not calculated as not part of top twenty manufacturers in respective country.

Sources: Estimation based on data from EIA (2013); GAIN (2012); RFA (2013); UNICA (2010), firm websites and annual reports. 